Review

\title{
MicroRNA-Regulated Signaling Pathways: Potential Biomarkers for Pancreatic Ductal Adenocarcinoma
}

\author{
Maria Mortoglou $^{1}\left(\mathbb{D}\right.$, David Wallace ${ }^{2} \mathbb{D}$, Aleksandra Buha Djordjevic ${ }^{3} \mathbb{D}$, Vladimir Djordjevic $^{4}$, \\ E. Damla Arisan 5 (D) and Pinar Uysal-Onganer $1, *$ (D)
}

1 Cancer Research Group, School of Life Sciences, University of Westminster, London W1W 6UW, UK; w1754188@my.westminster.ac.uk

2 Department of Pharmacology \& Physiology, Oklahoma State University Center for Health Sciences, 1111 West 17th Street, Tulsa, OK 74107-1898, USA; david.wallace@okstate.edu

3 Department of Toxicology, University of Belgrade, 11000 Belgrade, Serbia; aleksandra@pharmacy.bg.ac.rs

4 First Surgical Clinic, Clinical Center of Serbia, 11000 Belgrade, Serbia; vladimir.djordjevic@kcs.ac.rs

5 Institution of Biotechnology, Gebze Technical University, 41400 Gebze, Turkey; damlaarisan@gmail.com

* Correspondence: p.onganer@westminster.ac.uk

check for

updates

Citation: Mortoglou, M.; Wallace, D.; Buha Djordjevic, A.; Djordjevic, V.; Arisan, E.D.; Uysal-Onganer, P. MicroRNA-Regulated Signaling Pathways: Potential Biomarkers for Pancreatic Ductal Adenocarcinoma. Stresses 2021, 1, 30-47. https:// doi.org/10.3390/stresses1010004

Received: 10 February 2021

Accepted: 5 March 2021

Published: 10 March 2021

Publisher's Note: MDPI stays neutral with regard to jurisdictional claims in published maps and institutional affiliations.

Copyright: (c) 2021 by the authors. Licensee MDPI, Basel, Switzerland. This article is an open access article distributed under the terms and conditions of the Creative Commons Attribution (CC BY) license (https:/ / creativecommons.org/licenses/by/ $4.0 /)$.

\begin{abstract}
Pancreatic ductal adenocarcinoma (PDAC) is the most aggressive and invasive type of pancreatic cancer (PCa) and is expected to be the second most common cause of cancer-associated deaths. The high mortality rate is due to the asymptomatic progression of the clinical features until the advanced stages of the disease and the limited effectiveness of the current therapeutics. Aberrant expression of several microRNAs (miRs/miRNAs) has been related to PDAC progression and thus they could be potential early diagnostic, prognostic, and/or therapeutic predictors for PDAC. miRs are small (18 to 24 nucleotides long) non-coding RNAs, which regulate the expression of key genes by targeting their 3 '-untranslated mRNA region. Increased evidence has also suggested that the chemoresistance of PDAC cells is associated with metabolic alterations. Metabolic stress and the dysfunctionality of systems to compensate for the altered metabolic status of PDAC cells is the foundation for cellular damage. Current data have implicated multiple systems as hallmarks of PDAC development, such as glutamine redox imbalance, oxidative stress, and mitochondrial dysfunction. Hence, both the aberrant expression of miRs and dysregulation in metabolism can have unfavorable effects in several biological processes, such as apoptosis, cell proliferation, growth, survival, stress response, angiogenesis, chemoresistance, invasion, and migration. Therefore, due to these dismal statistics, it is crucial to develop beneficial therapeutic strategies based on an improved understanding of the biology of both miRs and metabolic mediators. This review focuses on miRmediated pathways and therapeutic resistance mechanisms in PDAC and evaluates the impact of metabolic alterations in the progression of PDAC.
\end{abstract}

Keywords: cancer; microRNAs; cell signaling pathways; metabolic stress

\section{Introduction}

Pancreatic ductal adenocarcinoma (PDAC) is highly lethal and a major cause of cancerassociated deaths in Western countries [1]. The poor prognosis of PDAC is the outcome of late diagnosis of the disease when the tumor is locally advanced or has metastasized [2]. PDAC can be characterized as a "silent killer", since it has the smallest overall survival rate of all human cancers [3]; the median survival rate does not exceed 5 to 8 months [4]. PDAC prognosis is poor due to enhanced cell proliferation, invasion, and metastatic features in combination with the chemo- and radiotherapy resistance of PDAC cells [5]. Consequently, early-stage diagnostic biomarkers and efficient therapeutic strategies are crucial for minimizing PDAC-related deaths [6].

In recent years, numerous important findings have been discovered in relation to the molecular biology of PDAC in diagnosis, staging, and treatment [7]. However, since 
PDAC is a highly metastatic malignancy, only a small portion of PDAC patients have benefited from an improvement in overall survival rates [7,8]. Gemcitabine is the first drug treatment that improved median survival, but only by a few weeks [9]. Another commonly used chemotherapy agent, FOLFIRINOX (5-FU, irinotecan, oxaliplatin, and leucovorin), combined with gemcitabine has been suggested to elevate the median survival rate to 11.1 months, in contrast to 6.8 months with gemcitabine alone [10]. Nevertheless, the limitations of the current therapeutic options for PDAC accentuate the importance of a better understanding of the molecular mechanisms and pathways linked to PDAC. Therefore, through a better understanding of the modified molecular signaling, we would have the ability to diagnose PDAC early in the progression of the disease and develop beneficial therapeutic regimens that could abort the aggressiveness of PDAC [11].

PDAC development originates from pre-cancerous lesions to pancreatic intraepithelial neoplasia (PanIN-I, -II, or -III) to more advanced invasion and metastasis, which is associated both with the activation of several oncogenes and the inactivation of tumor suppressors [12]. The most common genetic alterations linked to PDAC development are mutations in Kirsten rat sarcoma viral homolog $(K-R A S)$ and the overexpression of human epidermal growth factor receptor (HER-2/neu) [13]. At later stages (PanIN-III or -IV), the inactivation of tumor suppressor genes (TS), including cyclin-dependent kinase inhibitor 2A (CDKN2A), tumor protein 53 (TP53) and Sma- and Mad-related protein (SMAD) family number $4(S M A D 4)[13,14]$, has been considered as a key regulator of PDAC pathogenesis [15]. Moreover, previous studies have revealed that 12 main signaling pathways, comprising KRAS signaling, Hedgehog signaling, apoptosis, control of G1/S phase transition and transforming growth factor (TGF- $\beta$ ) signaling, are dysregulated in more than $80 \%$ of PDAC patients $[16,17]$. Modifiable risk factors can significantly increase the risk of PDAC development up to 132-fold [18]. Some of these risks include chronic pancreatitis development, diabetes mellitus, and some infectious diseases [19]. Additionally, environmental exposures can induce PDAC development through various mechanisms, such as the inhalation of cigarette smoke, exposure to mutagenic nitrosamines or chlorinated hydrocarbon solvents, and exposure to toxic metals such as arsenic, nickel, and cadmium [20-26].

miRs are small (18 to 28 nucleotides long), endogenous, non-coding, evolutionary conserved, single-stranded RNA molecules that have been shown to moderate gene expression at the posttranscriptional level through binding to the complementary sequences of their target mRNAs at the $3^{\prime}$ untranslated region (UTRs) [27]. Based on the interactions between the $3^{\prime}$ untranslated region ( $3^{\prime}$ UTR) and mRNAs, miRs can control the expression levels of several genes and also regulate a number of cell signalling pathways related to tumorigenesis [28]. miRs play a significant role not only in cell growth and development, but also in cell survival and lipid/glucose metabolic pathways in numerous carcinomas and autoimmune diseases [29,30]. Consequently, alterations in the expression of miRs can cause apoptosis, angiogenesis, and metastasis [31]. Specifically, epithelial-mesenchymal transition (EMT) can be considered as a key component of the metastatic cascade, which includes the repression of E-cadherin and the activation of genes related to motility and invasion [32]. miRs can act as oncogenes (oncomiR) or tumor suppressor genes (tsmiR) [33]. Recent studies have suggested a correlation between aberrant expression levels of numerous miRs and PDAC, especially in the initiation, proliferation, and chemoresistance of PDAC $[34,35]$. miRs can be characterized as vital biomarkers not only for the early prognosis and diagnosis of PDAC, but also for better management of therapeutic specimens [36]. Identifying the most commonly expressed miRs and their related signaling pathways is crucial for a better understanding of PDAC pathophysiology. The aim of this review is to explore the signaling pathways that are associated with PDAC prognosis and metastasis via miR signatures. 


\section{Signaling Pathways Associated with PDAC}

\subsection{TGF- $\beta$ and HGF-MET Signaling Pathways}

SMADs have been widely associated with PDAC progression and are involved in several biological processes, such as cell proliferation, differentiation, and apoptosis, in PDAC pathogenesis [37] through the transduction of the TGF- $\beta$ signaling pathway. The TGF- $\beta$ pathway is regulated by three principal target genes, including TGFBR2, SMAD3 and SMAD4, which are involved in cell growth, differentiation, and cell cycle progression in PDAC [38]. Specifically, TGF- $\beta$ is one of the most critical EMT-inducing factors in several malignancies, including PDAC [39]. Moreover, SMAD4 mutations are common in the TGF- $\beta$ pathway [40] and are found in $60 \%$ of PDAC cases [16], where it is associated with a higher risk of metastasis and poor prognosis [41,42]. SMAD4 inactivation is present in the late stages of PDAC development, while normal expression of SMAD4 is observed in early PanIN lesions [40]. Specifically, TGF- $\beta$ moderates EMT, metastasis, extravasation of colonization sites, and escape from immune surveillance in advanced and metastatic PDAC cases [43]. A study by Li et al. stated that the loss of SMAD4 can cause elevated levels of forkhead Box M1 (FOXM1), nuclear localization of $\beta$-catenin, and decreased levels of miR-494 [44], which results not only in elevated cell proliferation, migration, and invasion, but also in increased resistance to gemcitabine in PDAC patients [45]. Further miRs that are also linked to SMAD4 expression in PDAC are miR-421 and miR-483-3p [46,47]. The mesenchymal-epithelial transition factor gene (MET) can be activated as a response to hepatocyte growth factor (HGF) [45]. Specifically, Src, MEK-ERK1/2, PI3K-AKT, NK-кB, mTOR, and STAT are common effector molecules of the HGF-MET signaling cascade [48], and are associated with cell proliferation, migration, and survival [49]. In PDAC, elevated MET expression levels have been observed and linked to tumor-node-metastasis (TNM) stage [49]. Furthermore, increased MET expression levels have also been correlated to epithelial-mesenchymal transition (EMT)-like changes and gemcitabine resistance in PDAC [50]. In particular, miR-26a has been associated with the upregulation of MET in PDAC cancer stem cells [51]. A previous study has revealed that miR-424-5p is overexpressed in PDAC, and that it can also regulate the ERK1/2 signaling pathway through the negative modulation of SOCS6 [52].

\subsection{JAK-STAT Signaling Pathway}

Previous studies have shown that mutations in the JAK-STAT signaling pathway are closely associated with PDAC progression [45]. Specifically, downregulation of let7 has been determined in PDAC and has been associated not only with the decreased phosphorylation/activation of STAT3 and its downstream signaling events, but also with the downregulated growth and migration of PDAC cells [53]. The cytoplasmic expression of suppressor of cytokine signaling 3 (SOCS3) can be enhanced by let-7 re-expression, which further leads to the blockage of STAT3 activation by JAK2 [53]. Further miRs associated with the JAK-STAT pathway in PDAC are miR-216a, miR-130b, and miR-155 [54]. In particular, miR-216a is downregulated in PDAC and is the direct target of JAK2 [55]. Additionally, miR-130b is overexpressed in PDAC and binds directly to the 3'-UTR of STAT3 mRNA [56]. Aberrant expression of this miR is linked to poor prognosis, suppression of cell proliferation, and invasion in PDAC by inhibiting STAT3 [56]. miR-155 is also closely correlated with the JAK-STAT signaling pathway [54] through the inhibition of SOCS1, which further promotes PDAC cell invasion and migration [57].

\subsection{PI3K-AKT Signaling Pathway}

The PI3K-AKT signaling pathway is associated with cell proliferation and the inhibition of apoptosis in PDAC [58]. Specifically, PI3K-AKT-mTOR signaling, which is suppressed by PTEN, can be targeted by miR-21, miR-221, and miR-181a [59-62]. miR-21 inhibits cell cycle arrest, apoptosis, and gemcitabine sensitivity [59], and thus the inhibition of miR-221 can result in the uncontrolled proliferation and migration of PDAC cells $[60,63]$. miR-181a also prompts the migration of PDAC cells [61]. Controversially, miR-375 and 
miR-220c are also linked to the PI3K-AKT signaling pathway in PDAC [54]. PDK1 encodes a kinase downstream of PI3K and is the direct target of miR-375 [64]. Moreover, the upregulation of miR-200c is also linked to both EMT [65] and MUC4 expression in PDAC [66]. Specifically, MUC4 expression results not only in the stabilization of HER2, but also in the activation of AKT, which further leads to the activation of $\mathrm{N}$-cadherin $[67,68]$.

\subsection{TP53 Signaling Pathway and Apoptosis}

The loss of TP53 is detected in more than 70\% of PDAC patients, particularly in advanced cases, with the most common mutations being missense point mutations $[40,69]$. The inactivation of p53 has consequences for PDAC heterogeneity and chemoresistance [70] and results in the dysregulation of several biological processes, such as cell proliferation, migration, invasion, and apoptosis [71]. Some examples of miRs that can target p53 are miR-222 and miR-203 [72]. Previous studies have shown that TP53 directly regulates miR34 , which in turn targets NOTCH (which is responsible for the maintenance and survival of PDAC cells) [71]. Moreover, it has been shown that miR-155 downregulates the TP53induced nuclear protein 1 gene, which promotes PDAC progression [73]. Dysregulation of apoptosis is a common cause of chemoresistance in PDAC and can be caused by several stimulatory and inhibitory factors that are associated with a high number of miRs [74]. For example, oncogenic miR-21 is observed in several cancer types and controls genes that are necessary for apoptosis [75]. Additionally, miR-23a can target APAF1, which results in the activation of caspase- 9 and prompts apoptosis in several cancer types, including PDAC [76]. Furthermore, in PDAC, a decrease in the expression levels of BIM has been observed through the modulation of miR-24, which inhibits apoptosis and the cell cycle [76].

\subsection{KRAS Signaling Pathway}

K-RAS mutations have been reported not only in more than $90 \%$ of PDAC patients, but also in colorectal cancer, lung adenocarcinomas, and urogenital cancers [77,78]. In recent years, numerous miRs have been found to be key regulators of the KRAS signaling pathway in PDAC. Specifically, miR-217 acts as a tumor suppressor in PDAC, which directly targets the KRAS oncogene [79]. miR-217 causes a decrease in the constitutive phosphorylation of the downstream signal transducer $A K T$ [79]. A study by Yu et al. also suggested that miR-96 not only targets KRAS, but also negatively modulates the phosphorylated AKT signaling pathway downstream of KRAS [80]. Further studies have also observed that miR-126 and let-7d target KRAS via post-transcriptional upregulation [81]. Moreover, the miR-21 promoter can be stimulated by activated KRAS (G12D) in PDAC cells [82], which has been linked to poor prognosis in PDAC [16]. miR-206 acts as a tumor suppressor in PDAC and was found to inhibit both the KRAS and ANXA2 oncogenes [83]. Hence, miR206 can be a negative regulator of oncogenic KRAS-induced NF-KB transcriptional activity, which leads to reduced proangiogenic and proinflammatory factors that further result in tumor growth and poor prognosis [84]. miR-27a has been found to be overexpressed in PDAC and has been linked to reduced cell growth and migration [54]. Specifically, miR-27a is the direct target of Sprouty2, which controls KRAS expression [85]. The overexpression of miR-143/145 is repressed by activated KRAS, which promotes the growth of PDAC cells [86]. Additionally, activated KRAS can stimulate downstream signaling components, including MAP2K1/MEK and MAPK1/ERK2 $[15,87,88]$. Collisson et al. have shown that the MAPK signaling pathway is involved in the genesis of PanIN, especially in the early stages of PDAC development [89]. Therefore, further understanding of the oncogenic role of KRAS in PDAC could lead to novel strategies for earlier diagnosis and a more effective targeted therapy for this malignancy.

\subsection{Epidermal Growth Factor Receptor and HER2/neu Signaling Pathways}

The epidermal growth factor receptor (EGFR) family is a group of cytoplasmic receptor tyrosine kinases that contains the human EGF receptor or Her1 (EGFR or ErbB-1), Her2 (EGFR2 or ErbB-2), Her3 (EGFR3 or ErbB-3), and Her4 (EGFR4 or ErbB-4) [40]. Specifically, 
ErbB-2 is commonly upregulated in PDAC, particularly in PanIN lesions and carcinoma in situ lesions [40] and has been linked with invasion [40]. Moreover, two common ligands of EGFR, EGF and TGF- $\alpha$, are significantly upregulated in PDAC tissues [40]. In particular, TGF- $\alpha$ can activate Notch signaling downstream of EGFR signaling [90]. Similarly, ErbB-3 has been also found to be overexpressed in PDAC patients with advanced tumor stages and limited survival time [91]. Hence, it has been suggested that targeting EGFR could be an effective therapeutic strategy in PDAC patients [40]. Subsequently, ErbB-1 has been linked to both aggressiveness and unfavorable prognosis in PDAC cases [92]. Furthermore, EGFR upregulation is observed in more than $95 \%$ of PDAC cases and is closely associated with the aberrant expression of numerous miRs in PDAC [93]. A study by Du Rieu et al. indicated that EGFR could promote the overexpression of miR-21 in PDAC cells [94]. A further study by Ali et al. showed a correlation between miR-146a and the upregulation of EGFR in PDAC cells [93]. Another study also demonstrated that miR-200c can directly target the expression levels of mitogen-inducible gene 6 (MIG6), which is a negative modulator of EGFR [95]. The HER2/neu signaling pathway plays a key role in PDAC prognosis [96], as $4-50 \%$ of PDAC cases show HER2 upregulation [97]. Recent studies have suggested a correlation between miR-150 and the HER2/neu signaling pathway [45]; in particular, miR-150 is upregulated in PDAC and results in a considerable reduction in the expression levels of its target gene, MUC4 [45].

\subsection{Notch and Hedgehog Signaling Pathways}

The Notch signaling pathway, which is crucial for tissue proliferation, the development of organs, cell differentiation, and apoptosis, has been linked with poor prognosis in PDAC $[73,98]$. The oncogenic role of Notch homolog 1 (Notch) activation contributes to stem cell self-renewal, cell proliferation, apoptosis, migration, invasion, metastasis, and angiogenesis [99]. Blocking of the Notch signaling pathway is related to the attenuation of NF- $\mathrm{kB}$ activity and upregulation of p21 and p27 [100]. Elevated expression of Notch pathway genes is present in early PanIN lesions [90]. It has been demonstrated that several miRs are associated with the Notch pathway in PDAC [83]. Specifically, miR-34 can be directly regulated by TP53, which further leads to the downstream signaling of Notch targets [83]. Moreover, Notch-1/2 can be downregulated through the restoration of miR-34 expression in PDAC cancer stem cells (CSCs) [101]. Furthermore, treatment of PDAC stem cells with chromatin-modulating agents can also lead to the suppression of miR-34 targets such as $B c l-2, C D K 6$, and SIRT1 [71]. A further study by Brabletz and colleagues suggested that miR-200 can inhibit Notch pathway components such as Jagged1 and the mastermind-like coactivators Maml2 and Maml3, which further prompt the enhancement of Notch activation through EMT and ZEB1 [102]. Other studies have also remarked that the upregulation of miR-145 and downregulation of let-7a and miR-200 causes not only a decrease in the expression of EMT-related transcription factors, but also the inhibition of Notch1 via miR-144 [103]. The Hedgehog signaling pathway $(\mathrm{HH})$ acts as a regulator of embryonic development but is also responsible for the moderation of CSCs [104]. Specifically, several cases with deregulations in HH signaling have been observed in PDAC [105]. Previous studies have shown that the activity of this pathway is upregulated in PanIN lesions, which suggests that $\mathrm{HH}$ could be a regulator of the early and late stages of PDAC pathogenesis [105]. The HH pathway also plays a crucial role in cell cycle progression and apoptosis in PDAC [40]. Hence, the inhibition of several HH pathway components could be a novel therapeutic strategy for PDAC [40]. A study by Dosch et al. has demonstrated that Hedgehog, which is a secreted ligand, can bind to its receptor, Patched1 (PTCA1) [106]. In PDAC, PTCA1 can be downregulated by miR-212, which is overexpressed in this malignancy. This could lead to unfavorable effects on cell growth, migration, and invasion via the HH pathway [107]. 


\subsection{Wnt/ß-Catenin Signaling Pathway}

The WNT/ $\beta$-catenin signaling pathway plays a crucial role in several biological and cellular processes, such as proliferation, differentiation, invasion, and migration, while it can also affect the PDAC tumor cell compartment [54]. miR-29c, which is downregulated in PDAC, can be suppressed by TGF- $\beta$ but can also moderate the regulators upstream of WNT, including FZD4, FZD5, FRAT2, and LRP-6 [108]. Similarly, miR-29a expression levels are associated with both the resistance of PDAC cells to gemcitabine and with the activation of the Wnt/ $\beta$-catenin signaling pathway [109]. Moreover, this pathway can be activated when the cell membrane of the WNT receptor is bound to its ligands, which leads to the release of $\beta$-catenin into the cytoplasm [40]. The elevated expression of $\beta$-catenin is observed in most PDAC cases [110], especially in the later stages of PanIN lesion development [111].

\subsection{Cell Cycle Signaling Pathway and $p 16 / C D K N 2 A$ Inactivation}

The cell cycle is controlled by the activity of Cdk/cyclins, which regulate several mechanisms in normal cells [112]. The overexpression of cyclin D1 and downregulation of p16 have been found in several PDAC cases [113]. Recent studies have shown that a high number of miRs are associated with dysregulations in cell cycle signaling [54]. Specifically, cyclin D1-dependent kinase can be targeted by miR-107 to initiate cell cycle progression [112], whereas, in PDAC, miR-107 can be silenced through the methylation of CpG islands in its $5^{\prime}$ promoter region [114]. A study by Zhao et al. has shown that miR-192 results in the promotion of cell proliferation, and it can also moderate cycle progression via the G1 to S-phase transition in PDAC cells [115]. This study revealed that the overexpression of miR-192 led to an elevated expression of cyclin D1, cyclin D2, $C D K 4$, and $C D C 2$ [115]. Further research denoted that miR-301a is responsible for the promotion of PDAC cell proliferation through the inhibition of the Bim gene [116], which acts as an initiator of apoptosis through the generation of multidomain pro-apoptotic proteins, including Bak and Bax [117]. Additionally, miR-193b can deregulate the action of the KRAS pathway in PDAC [83]. miR-193b acts as a cell cycle brake in PDAC, which induces G1-phase arrest and reduces the fraction of cells in the $S$ phase [118]. miR-223 can indirectly target cyclin E2, which further inhibits FBXW7 [11,119]. Moreover, cyclin E2 can be also targeted by p27 and p57, which negatively regulate G1/S progression via miR-222 [59,120]. Conclusively, a previous study has also indicated that miR-148a can target $C D C 25 B$, which controls the activation of distinct CDK/cyclin complexes [121]. This can lead to the inhibition of PDAC cell phenotype [122]. The $p 16-$ Ink $4 A$ locus is encoded by the CDKN2A tumor suppressor gene [123] and alterations in the expression levels of Ink4 $A$ have been found in 95\% of PDAC cases [124]. Loss of p16 is linked to early PanIN lesions through invasive carcinomas [125]. P16 is a well-described cyclin-dependent kinase inhibitor which binds to $C D K 4$ and $C D K 6$ [126]; it is the product of the CDKN2A gene and is connected to PDAC [127]. p16 is involved in the inhibition of the activity of phosphorylated retinoblastoma $(p R b)$, which is responsible for G1/S transition [126]. Moreover, specific miRs such as miR-222 can directly target p27 and p57, which are essential cell cycle inhibitors [128]. A further study has also denoted that dysregulated expression levels of both miR-132 and miR-212 can cause G2/M cell cycle arrest and decreased cell proliferation in PDAC [129]. Nevertheless, these mechanisms have not been fully understood in PDAC and therefore the examination of these pathway regulators in PDAC is vital [130].

\subsection{Transcription Factors and DNA Methylation}

Transcription factors can affect the downstream gene transcription of signal transduction pathways which are targeted not only by genetic alterations, but also through epigenetic alterations, which lead to the aggressiveness of PDAC [131]. Specifically, both DNA methylation and histone tail alterations are associated with epigenetic modulation through chromatin remodeling [132]. Controversially, forkhead members of the class $\mathrm{O}$ (FOXO) transcription factors have been characterized as tumor suppressors in numerous biological processes, such as stress resistance, metabolism, cell cycle, apoptosis, oxidative 
stress, [133] and DNA repair [134]. miR-21 can target FOXO1, which promotes PDAC growth in vivo [135]. Similarly, FOXO3a can be targeted by miR-155 in PDAC, which further leads to cell proliferation and metastasis through the generation of reactive oxygen species [136]. The FOXM1 transcription factor can be overexpressed through the regulation of miR-200b expression in PDAC [137]. In addition, $N F-\kappa B$ is closely related to several cellular processes and its expression is attributed to the aggressiveness of PDAC [138]. $N F-\kappa B$ can be downregulated upon the upregulation of miR-146a in PDAC [139]; NF- $\kappa B$ activity can be also increased via miR-301a in PDAC, which results in increased tumor growth [140]. Previous studies have also revealed that DNA methylation plays a crucial role during PDAC development [141]. Specifically, DNA methyltransferase 1 (DNMT1) is commonly upregulated in several cancer types [142], including PDAC, and can be targeted both by miR-148b and miR-152 [143]. Moreover, in PDAC, miR-141 can directly target Yes-associated protein 1 (YAP1), which is a main downstream effector of the protein kinase Hpo (HIPPO) pathway. The HIPPO pathway controls tissue homeostasis, organ size, regeneration, and tumorigenesis [144]. miR-217 can directly target sirtuin 1 (SIRT1), which is an NAD-dependent deacetylase that regulates cell proliferation, differentiation, apoptosis, metabolism, DNA damage, stress responses, genome stability, and cell survival [145]. Upregulated SIRT1 can also generate EMT in PDAC patients [146] (Table 1, Figure 1).

Table 1. MicroRNAs (miRs) and their expression levels and functions in pancreatic ductal adenocarcinoma (PDAC).

\begin{tabular}{|c|c|c|c|c|c|}
\hline miRs & $\begin{array}{l}\text { Regulation in } \\
\text { PDAC }\end{array}$ & $\begin{array}{l}\text { Signaling Pathways } \\
\text { Involved }\end{array}$ & Target Genes & $\begin{array}{l}\text { Functional Involvement in } \\
\text { PDAC }\end{array}$ & References \\
\hline let-7 & Down & $\begin{array}{l}\text { JAK-STAT } \\
\text { K-RAS }\end{array}$ & $\begin{array}{c}\text { STAT3, SOCS3, } \\
\text { N-cadherin, ZEB1 }\end{array}$ & Tumor growth, migration & [53] \\
\hline let-7a & Up & $\mathrm{NOTCH}$ & JAK, STAT & EMT & [103] \\
\hline let-7d & Up & K-RAS & KRAS & $\begin{array}{l}\text { Cell proliferation, migration, } \\
\text { invasion, apoptosis }\end{array}$ & [81] \\
\hline $\operatorname{miR}-21$ & Up & $\begin{array}{l}\text { PI3K-AKT } \\
\text { K-RAS } \\
\text { EGFR } \\
\text { Cell cycle } \\
\text { Apoptosis }\end{array}$ & $\begin{array}{l}\text { G12D, p27, p57, } \\
\text { FOXO1, Bcl-2, } \\
\text { FasL, PI3K, AKT, } \\
\text { PTEN, RECK, } \\
\text { SPRY2 }\end{array}$ & $\begin{array}{c}\text { Cell cycle arrest, apoptosis, } \\
\text { gemcitabine resistance, } \\
\text { aggressiveness }\end{array}$ & {$[59,82,94]$} \\
\hline miR-23a & Up & Apoptosis & APAF1 & Apoptosis & [76] \\
\hline miR-24 & Up & Apoptosis & BIM & Apoptosis, cell cycle & [76] \\
\hline miR-26a-5p & Down & HGF-MET & $\begin{array}{l}\text { ARMTL2, Cyclin } \\
\text { E2, MMP12 }\end{array}$ & $\begin{array}{c}\text { Cell proliferation, migration, } \\
\text { survival, EMT }\end{array}$ & [51] \\
\hline miR-27a & Up & K-RAS & Sprouty2 & $\begin{array}{l}\text { Cell proliferation, migration, } \\
\text { invasion, apoptosis }\end{array}$ & [85] \\
\hline miR-29a & Up & Wnt & MUC1 & $\begin{array}{c}\text { Cell proliferation, } \\
\text { differentiation, invasion, } \\
\text { migration, gemcitabine } \\
\text { resistance }\end{array}$ & [109] \\
\hline $\operatorname{miR}-29 \mathrm{c}$ & Down & Wnt & $\begin{array}{l}\text { ZD4, FZD5, } \\
\text { FRAT2, LRP-6 }\end{array}$ & $\begin{array}{c}\text { Cell proliferation, } \\
\text { differentiation, invasion, } \\
\text { migration }\end{array}$ & [108] \\
\hline $\operatorname{miR}-34 a$ & Down & $\begin{array}{c}\mathrm{Tp} 53 \\
\mathrm{NOTCH}\end{array}$ & $\begin{array}{l}\text { NOTCH1/2CDK6, } \\
\text { SIRT1 }\end{array}$ & $\begin{array}{l}\text { Cell proliferation, migration, } \\
\text { invasion, apoptosis }\end{array}$ & {$[71,83]$} \\
\hline $\mathrm{miR}-96 \mathrm{~b}$ & Down & K-RAS & KRAS, AKT & $\begin{array}{l}\text { Cell proliferation, migration, } \\
\text { invasion, apoptosis }\end{array}$ & [80] \\
\hline
\end{tabular}


Table 1. Cont.

\begin{tabular}{|c|c|c|c|c|c|}
\hline miRs & $\begin{array}{l}\text { Regulation in } \\
\text { PDAC }\end{array}$ & $\begin{array}{l}\text { Signaling Pathways } \\
\text { Involved }\end{array}$ & Target Genes & $\begin{array}{l}\text { Functional Involvement in } \\
\text { PDAC }\end{array}$ & References \\
\hline miR-107 & Up & Cell cycle & $\begin{array}{l}\text { Cyclin } \\
\text { D1-dependent } \\
\text { kinase }\end{array}$ & Cell proliferation & [114] \\
\hline miR-126 & Down & K-RAS & KRAS & $\begin{array}{l}\text { Cell proliferation, migration, } \\
\text { invasion, apoptosis }\end{array}$ & [81] \\
\hline miR-130b & Down & JAK-STAT & STAT3 & Cell proliferation, invasion & {$[54,56]$} \\
\hline miR-132 & Up & P16 & $\mathrm{Rb} 1$ & $\begin{array}{l}\text { G2/M cell cycle arrest, cell } \\
\text { proliferation }\end{array}$ & [129] \\
\hline miR-141 & Down & DNA methylation & YAP1, MAP4K4 & $\begin{array}{l}\text { Tissue homeostasis, organ } \\
\text { size, regeneration }\end{array}$ & [144] \\
\hline miR-143 & Down & K-RAS & $\begin{array}{l}\text { KRAS, MMP-2, } \\
\text { MMP1 }\end{array}$ & Tumor growth & [86] \\
\hline miR-144 & Down & NOTCH & PRR11 & EMT & [103] \\
\hline miR-145 & Down & $\begin{array}{l}\text { K-RAS } \\
\text { NOTCH }\end{array}$ & KRAS & Tumor growth, EMT & {$[86,103]$} \\
\hline miR-146a & Down & EGFR & $\begin{array}{l}\text { EGFR, NF-kB, } \\
\text { IRAK-1 }\end{array}$ & Increased tumor growth & [93] \\
\hline miR-148a & Down & Cell cycle & CDC25B & $\begin{array}{c}\text { Cell proliferation, } \\
\text { differentiation, invasion, } \\
\text { migration }\end{array}$ & [121] \\
\hline $\operatorname{miR}-148 b$ & Down & DNA methylation & DNMT1, AMPKa1 & $\begin{array}{c}\text { Cell proliferation, } \\
\text { differentiation, invasion, } \\
\text { migration }\end{array}$ & [143] \\
\hline $\mathrm{miR}-150$ & Up & HER-2/neu & MUC4, IGF-1R & Invasion, migration & [45] \\
\hline $\operatorname{miR}-152$ & Down & DNA methylation & DNMT1 & $\begin{array}{c}\text { Cell proliferation, } \\
\text { differentiation, invasion, } \\
\text { migration }\end{array}$ & [143] \\
\hline miR-155 & Up & $\begin{array}{l}\text { JAK-STAT } \\
\text { Tp53 }\end{array}$ & $\begin{array}{c}\text { SOCS1 } \\
\text { TP53-induced } \\
\text { nuclear protein } 1 \\
\text { gene, FOXO3a, } \\
\text { RHOA, SMAD1/5, } \\
\text { ZNF652 } \\
\end{array}$ & $\begin{array}{l}\text { Cell invasion, migration, } \\
\text { metastasis, generation of } \\
\text { reactive oxygen species }\end{array}$ & {$[54,57,73]$} \\
\hline miR-181a & Up & PI3K-AKT & PTEN & Migration & [61] \\
\hline miR-192 & Up & Cell Cycle & $\begin{array}{l}\text { Cyclin D1, cyclin } \\
\text { D2, CDK4 }\end{array}$ & Cell proliferation & [115] \\
\hline $\mathrm{miR}-193 \mathrm{~b}$ & Down & Cell Cycle & KRAS & G1-phase arrest & [118] \\
\hline miR-200 & Up & $\mathrm{NOTCH}$ & $\begin{array}{c}\text { Jagged1, } \\
\text { Maml2,Maml3 }\end{array}$ & EMT & [102] \\
\hline miR-200c & Down & EGFR & MIG6, EP300 & Invasion, migration & [95] \\
\hline miR-203 & Up & Tp53 & p53 & $\begin{array}{l}\text { Cell proliferation, migration, } \\
\text { invasion, apoptosis }\end{array}$ & {$[72]$} \\
\hline miR-206 & Down & K-RAS & KRAS, ANXA2 & $\begin{array}{l}\text { Decrease in proangiogenic } \\
\text { and proinflammatory } \\
\text { mediators, tumor growth, } \\
\text { progression }\end{array}$ & {$[83,84]$} \\
\hline
\end{tabular}


Table 1. Cont

\begin{tabular}{|c|c|c|c|c|c|}
\hline miRs & $\begin{array}{l}\text { Regulation in } \\
\text { PDAC }\end{array}$ & $\begin{array}{l}\text { Signaling Pathways } \\
\text { Involved }\end{array}$ & Target Genes & $\begin{array}{c}\text { Functional Involvement in } \\
\text { PDAC }\end{array}$ & References \\
\hline miR-212 & Up & $\begin{array}{c}\text { P16 } \\
\text { Hedgehog }\end{array}$ & $\mathrm{Rb} 1$ & $\begin{array}{l}\text { G2/M cell cycle arrest, cell } \\
\text { proliferation }\end{array}$ & {$[107,129]$} \\
\hline miR-216a & Down & JAK-STAT & JAK2 & Cell proliferation, invasion & {$[54,55]$} \\
\hline miR-217 & Down & K-RAS, DNA methylation & KRAS, SIRT1 & $\begin{array}{l}\text { Cell proliferation, migration, } \\
\text { invasion, apoptosis, } \\
\text { metabolism, DNA damage, } \\
\text { stress responses, genome } \\
\text { stability, cell survival }\end{array}$ & {$[79,145]$} \\
\hline miR-220c & Up & PI3K-AKT & MUC4 & EMT & [54] \\
\hline $\operatorname{miR}-221$ & Up & PI3K-AKT & $\begin{array}{l}\text { Cdk4, p16, E2F, } \\
\text { CDKN1B, MMP-2, } \\
\text { MMP-9, PUMA, } \\
\text { PTEN, MDM2, } \\
\text { ICAM-1, P27, BIM, } \\
\text { SOD2, STAT5A }\end{array}$ & Proliferation, migration & {$[60]$} \\
\hline miR-222 & Up & $\begin{array}{l}\text { Tp53 } \\
\text { P16 } \\
\text { Cell cycle }\end{array}$ & $\begin{array}{l}\text { p53, p27, p57, } \\
\text { MMP2, MMP9, } \\
\text { PUMA, PTEN, } \\
\text { BIM, MMP1, } \\
\text { SOD2, STAT5 }\end{array}$ & $\begin{array}{l}\text { Cell proliferation, migration, } \\
\text { invasion, apoptosis }\end{array}$ & {$[72,120,128]$} \\
\hline miR-223 & Up & Cell Cycle & FBXW7, Cyclin E2 & $\begin{array}{c}\text { Cell proliferation, } \\
\text { differentiation, invasion, } \\
\text { migration }\end{array}$ & {$[11,119]$} \\
\hline miR-301a & Up & Cell Cycle & $\begin{array}{l}\text { Bim, Bak, Bax, } \\
\text { NF-kB }\end{array}$ & Cell proliferation & [116] \\
\hline $\operatorname{miR}-375$ & Down & PI3K-AKT & PDK1 & $\begin{array}{c}\text { Cell proliferation, invasion, } \\
\text { migration }\end{array}$ & {$[54,64]$} \\
\hline $\operatorname{miR}-421$ & Up & TGF- $\beta$ & SMAD4 & $\begin{array}{l}\text { Cell proliferation, migration, } \\
\text { invasion }\end{array}$ & [46] \\
\hline $\operatorname{miR}-424-5 p$ & Up & HGF-MET & SOCS6 & $\begin{array}{c}\text { Cell proliferation, migration, } \\
\text { survival, EMT }\end{array}$ & {$[52]$} \\
\hline $\operatorname{miR}-483-3 p$ & Up & TGF- $\beta$ & SMAD4 & $\begin{array}{l}\text { Cell proliferation, migration, } \\
\text { invasion }\end{array}$ & [47] \\
\hline $\operatorname{miR}-494$ & Down & TGF- $\beta$ & FOXM1 & $\begin{array}{l}\text { Cell proliferation, migration, } \\
\text { invasion, increased resistance } \\
\text { to gemcitabine }\end{array}$ & [44] \\
\hline
\end{tabular}

JAK: Janus Kinase; STAT: Signal Transducer And Activator Of Transcription 3; ZEB: Zinc Finger E-Box Binding Homeobox 1; PI3K: Phosphatidylinositol-4,5-Bisphosphate 3-Kinase; AKT: AKT Serine/Threonine Kinase; BCL2: Apoptosis Regulator; FasL: Fas Ligand; PTEN: Phosphatase and Tensin Homolog; RECK: Reversion-inducing-cysteine-rich protein with kazal motifs; SPRY2: Sprouty homolog 2; APAF1: Apoptotic Peptidase Activating Factor 1; ARMTL2: Aryl Hydrocarbon Receptor Nuclear Translocator Like; MMP12: Matrix Metallopeptidase 12; FZD5: Frizzled Class Receptor 5; FRAT2: FRAT Regulator Of WNT Signaling Pathway 2; LRP-6: LDL Receptor Related Protein 6; Rb1: RB Transcriptional Corepressor 1; MAP4K4: Mitogen-Activated Protein Kinase Kinase Kinase Kinase 4; PRR11: Proline Rich 11; NF-kB: nuclear factor-kappa B; IRAK-1: Interleukin 1 Receptor Associated Kinase 1; CDC25B: Cell Division Cycle 25B; DNMT1 DNA Methyltransferase 1; RHOA: Ras Homolog Family Member A; ZNF652: Zinc Finger Protein 652; MAML2/3: Mastermind Like Transcriptional Coactivator 2/3; MIG6: Mitogen-inducible gene 6; EP300: E1A Binding Protein P300; ANXA2: Annexin A2; E2F1: E2F Transcription Factor 1; PUMA: p53 upregulated modulator of apoptosis; SOD2: Superoxide Dismutase 2; FBXW7: F-Box And WD Repeat Domain Containing 7; PDK1: Pyruvate Dehydrogenase Kinase 1. 


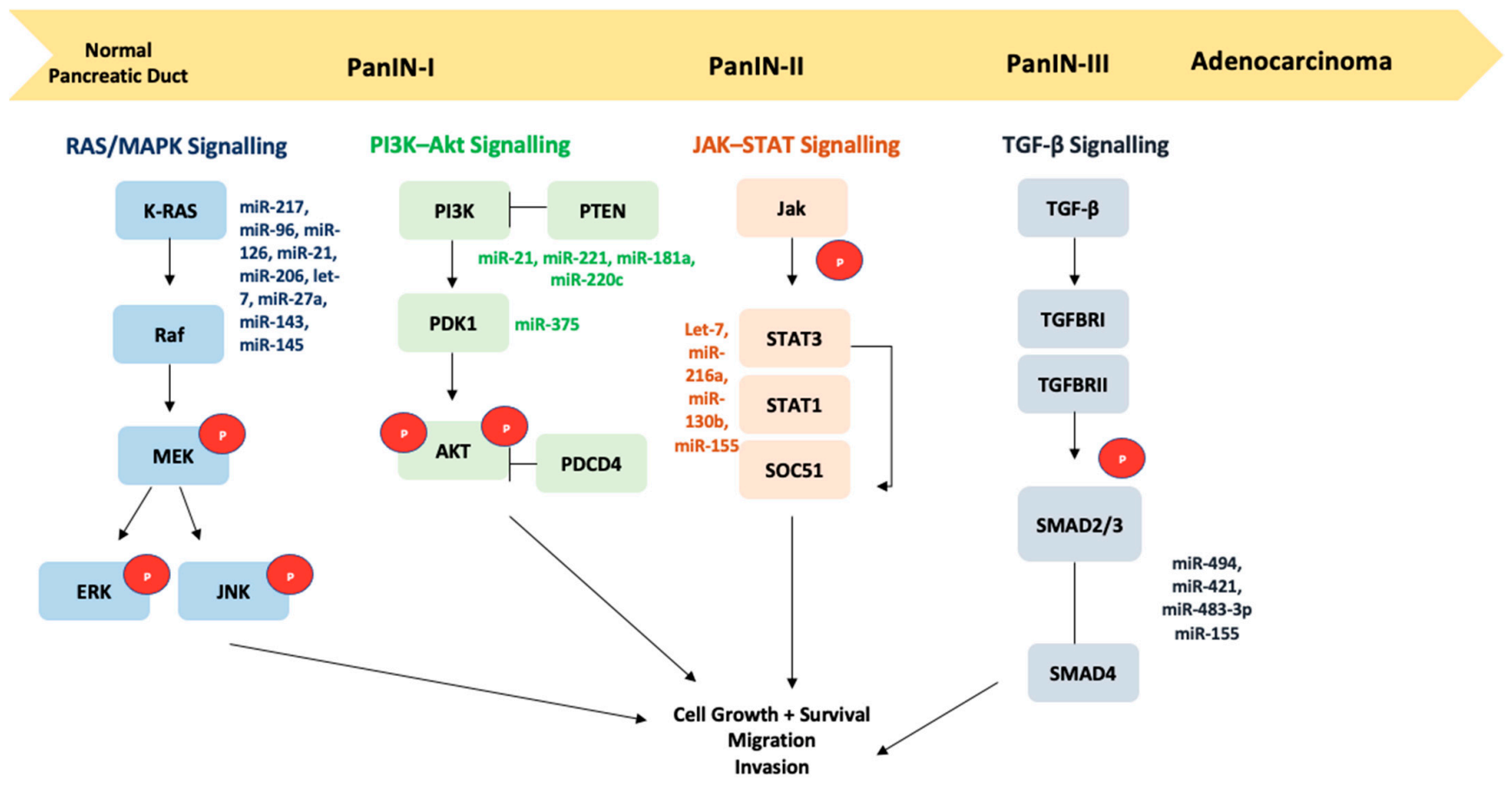

Figure 1. Mechanistic role of miRs in PDAC prognosis. miRs are involved in the main signaling pathways in PDAC. PDCD4: Programmed Cell Death 4 .

\section{Involvement of Metabolic Stress in PDAC}

Reprogramming of the cellular metabolic system occurs to accommodate the changes in cellular energy requirements needed during tumorigenesis. Glutamine is pivotal in regulating energy utilization [147-149]. Modifications that increase glutamine metabolism will attenuate the severity of PDAC. Increased expression and activity of 4-hydroxyphenylpyruvate dioxygenase-like protein (HPDL) promotes tumor formation, whereas reductions in HPDL expression inhibit cell growth [147]. Increased glutamine metabolism also protects cells from elevated oxidative stress. Numerous reports have discussed the potential for metabolic stress leading to increased oxidative stress [147,149-153]. Transcription factor EB (TFEB) has attracted a lot of interest recently for its ability to regulate PDAC growth. Elevated TFEB in PDAC has been shown to suppress both glutamine and mitochondrial metabolism [152]. Suppression of glutamine metabolism will lead to nutrient deprivationrelated stress in the cells, increasing oxidative stress and the expression of epidermal growth factor (EGFR) [154]. Glutamine is not only integral to cellular metabolism, but also to metastasis. Reductions in glutamine promote the transition from epithelial to mesenchymal cells in PDAC, which is regulated by Slug [155]. The E3 ubiquitin ligase, neural precursor cell-expressed developmentally downregulated gene 4-like (NEDD4L), has been shown to reduce mitochondrial metabolism and is negatively correlated with glutamine transporter (ASCT2) expression [154].

The modification of cellular energy metabolism by miRs has been shown for a few select miRs. The involvement of miR-1291 has been shown to reduce cell growth and metastasis, and that there can be an interaction between miR-1291, carnitine palmitoyltransferase, and estrogen receptor $\alpha$ [156]. The involvement of carnitine palmitoyltransferase $1 C$ (CPT1C) in the mitochondrial $\beta$-oxidation of fatty acids is important for cell survival. Low activity of CPT1C results in a negative cellular outcome with increased metabolic and oxidative stress, decreased cell growth, and dysregulated mitochondria [157]. Increasing the expression and activity of CPT1C reverses the negative cellular effects.

miR-143 is reported to be differentially expressed in patients following the ketogenic diet and has been identified as a metabolism-related biomarker [158]. miR-143 is downregulated in PDAC and associated with cytokine signaling pathways, nutrient metabolism, 
oxidative phosphorylation, and insulin signaling pathways to maintain metabolic homeostasis $[86,158]$. Additional work is needed to further establish connections between miRs and the metabolic stress process that occurs during tumorigenesis.

\section{Angiogenesis and miRs in PDAC}

Several previous studies have shown that numerous miRs are correlated to PDAC angiogenesis. Specifically, miR-34 is considerably downregulated in PDAC, while its upregulation can affect various biological processes, including angiogenesis, as well as apoptosis, cell cycle progression, and metastatic potential [101,159]. Guo et al. suggested that the upregulation of the tumor suppressor miR-410 could cause the inhibition of angiogenesis in PDAC [160]. It has also been stated that the inhibition of both miR-21 and miR-210 has been linked to the targeting of migration and invasion of PDAC cells and the suppression of angiogenesis [161]. A further study by Khan et al. reported that hypoxia-related angiogenic miRs, including miR-21, miR-200c, and miR-199, are commonly aberrantly expressed in PDAC [162]. In particular, hypoxia can promote PDAC cell migration, invasion, and angiogenesis in vitro through the induction of miR-21 [163]. Conclusively, miR-221/222 play a crucial role in the migration, invasion, angiogenic potential, and tumorigenicity of PDAC [164].

\section{Conclusions}

Understanding the relationship between the function and mechanism of miRs in PDAC is important as miRs have the potential to be used as novel biomarkers for the early diagnosis, prognosis, and therapeutic response in PDAC. miR-mediated altered metabolic mediators may play a crucial role in PDAC development through the dysregulation of several cellular functions, including proliferation, apoptosis, metastasis, and chemoresistance. The examination of these molecules can lead to a better understanding of the underlying molecular mechanisms that are responsible for the pathogenesis of PDAC. The clarification of the regulatory role of different miRs may elucidate a functional role in the therapy or diagnosis of PDACs. This review summarized the involvement of miR-mediated metabolic mediators and their affected regulatory pathways through modulating different genes that are responsible for PDAC progression. Further clinical studies are needed to identify the complex mechanisms and associations of miRs in PDAC.

Author Contributions: Writing—original draft preparation, M.M. and P.U.-O.; writing-review and editing, M.M., D.W., A.B.D., V.D., E.D.A. and P.U.-O. All authors have read and agreed to the published version of the manuscript.

Funding: M.M. is supported by University of Westminster SLS PhD Studentship.

Institutional Review Board Statement: Not applicable.

Informed Consent Statement: Not applicable.

Data Availability Statement: Not applicable.

Conflicts of Interest: The authors declare no conflict of interest.

\section{References}

1. Von Hoff, D.D.; Korn, R.; Mousses, S. Pancreatic Cancer-Could It Be that Simple? A Different Context of Vulnerability. Cancer Cell 2009, 16, 7-8. [CrossRef]

2. Srivastava, S.K.; Bhardwaj, A.; Singh, S.; Arora, S.; Wang, B.; Grizzle, W.E.; Singh, A.P. MicroRNA-150 directly targets MUC4 and suppresses growth and malignant behavior of pancreatic cancer cells. Carcinogenesis 2011, 32, 1832-1839. [CrossRef]

3. Siegel, R.; Ma, J.; Zou, Z.; Jemal, A. Cancer statistics, 2014. CA Cancer J. Clin. 2014, 64, 9-29. [CrossRef] [PubMed]

4. Baradaran, B.; Shahbazi, R.; Khordadmehr, M. Dysregulation of key microRNAs in pancreatic cancer development. Biomed. Pharmacother. 2019, 109, 1008-1015. [CrossRef] [PubMed]

5. Srivastava, S.K.; Arora, S.; Singh, S.; Bhardwaj, A.; Averett, C.; Singh, A.P. MicroRNAs in pancreatic malignancy: Progress and promises. Cancer Lett. 2014, 347, 167-174. [CrossRef] [PubMed]

6. Blum, R.S.; Kloog, Y. Metabolism addiction in pancreatic cancer. Cell Death Dis. 2014, 5, e1065. [CrossRef] 
7. Abbruzzese, J.L. Adjuvant therapy for surgically resected pancreatic adenocarcinoma. JAMA 2008, 299, 1066-1067. [CrossRef]

8. Neoptolemos, J.P.; Kleeff, J.; Michl, P.; Costello, E.; Greenhalf, W.; Palmer, D.H. Therapeutic developments in pancreatic cancer: Current and future perspectives. Nat. Rev. Gastroenterol. Hepatol. 2018, 15, 333-348. [CrossRef]

9. Olive, K.P.; Jacobetz, M.A.; Davidson, C.J.; Gopinathan, A.; McIntyre, D.; Honess, D.; Madhu, B.; Goldgraben, M.A.; Caldwell, M.E.; Allard, D.; et al. Inhibition of Hedgehog Signaling Enhances Delivery of Chemotherapy in a Mouse Model of Pancreatic Cancer. Science 2009, 324, 1457-1461. [CrossRef]

10. Conroy, T.; Desseigne, F.; Ychou, M.; Bouché, O.; Guimbaud, R.; Bécouarn, Y.; Adenis, A.; Raoul, J.-L.; Gourgou-Bourgade, S.; De La Fouchardière, C.; et al. FOLFIRINOX versus Gemcitabine for Metastatic Pancreatic Cancer. N. Engl. J. Med. 2011, 364, 1817-1825. [CrossRef]

11. Xu, W.; Taranets, L.; Popov, N. Regulating Fbw7 on the road to cancer. Semin. Cancer Biol. 2016, 36, 62-70. [CrossRef]

12. Maitra, A.; Hruban, R.H. Pancreatic Cancer. Annu. Rev. Pathol. Mech. Dis. 2008, 3, 157-188. [CrossRef] [PubMed]

13. Hezel, A.F.; Kimmelman, A.C.; Stanger, B.Z.; Bardeesy, N.; Depinho, R.A. Genetics and biology of pancreatic ductal adenocarcinoma. Genes Dev. 2006, 20, 1218-1249. [CrossRef]

14. Iacobuzio-Donahue, C.A.; Velculescu, V.E.; Wolfgang, C.L.; Hruban, R.H. Genetic Basis of Pancreas Cancer Development and Progression: Insights from Whole-Exome and Whole-Genome Sequencing. Clin. Cancer Res. 2012, 18, 4257-4265. [CrossRef] [PubMed]

15. Bükki, J. Pancreatic Adenocarcinoma. N. Engl. J. Med. 2014, 371, 2139-2141. [CrossRef]

16. Jones, S.; Zhang, X.; Parsons, D.W.; Lin, J.C.-H.; Leary, R.J.; Angenendt, P.; Mankoo, P.; Carter, H.; Kamiyama, H.; Jimeno, A.; et al. Core Signaling Pathways in Human Pancreatic Cancers Revealed by Global Genomic Analyses. Science 2008, 321, $1801-1806$. [CrossRef] [PubMed]

17. Sun, C.; Sang, M.; Li, S.; Sun, X.; Yang, C.; Xi, Y.; Wang, L.; Zhang, F.; Bi, Y.; Fu, Y.; et al. Hsa-miR-139-5p inhibits proliferation and causes apoptosis associated with down-regulation of c-Met. Oncotarget 2015, 6, 39756-39792. [CrossRef] [PubMed]

18. Becker, A.E.; Hernandez, Y.G.; Frucht, H.; Lucas, A.L. Pancreatic ductal adenocarcinoma: Risk factors, screening, and early detection. World J. Gastroenterol. 2014, 20, 11182-11198. [CrossRef]

19. Maisonneuve, P.; Lowenfels, A.B. Risk factors for pancreatic cancer: A summary review of meta-analytical studies. Int. J. Epidemiol. 2015, 44, 186-198. [CrossRef]

20. Barone, E.; Corrado, A.; Gemignani, F.; Landi, S. Environmental risk factors for pancreatic cancer: An update. Arch. Toxicol. 2016, 90, 2617-2642. [CrossRef] [PubMed]

21. Buha, A.; Wallace, D.; Matovic, V.; Schweitzer, A.; Oluic, B.; Micic, D.; Djordjevic, V. Cadmium Exposure as a Putative Risk Factor for the Development of Pancreatic Cancer: Three Different Lines of Evidence. BioMed Res. Int. 2017, 2017, 1-8. [CrossRef]

22. Djordjevic, V.R.; Wallace, D.R.; Schweitzer, A.; Boricic, N.; Knezevic, D.; Matic, S.; Grubor, N.; Kerkez, M.; Radenkovic, D.; Bulat, Z.; et al. Environmental cadmium exposure and pancreatic cancer: Evidence from case control, animal and in vitro studies. Environ. Int. 2019, 128, 353-361. [CrossRef]

23. Wallace, D.R.; Djordjevic, A.B. Heavy metal and pesticide exposure: A mixture of potential toxicity and carcinogenicity. Curr. Opin. Toxicol. 2020, 19, 72-79. [CrossRef]

24. Wallace, D.R.; Spandidos, D.A.; Tsatsakis, A.; Schweitzer, A.; Djordjevic, V.; Djordjevic, A.B. Potential interaction of cadmium chloride with pancreatic mitochondria: Implications for pancreatic cancer. Int. J. Mol. Med. 2019, 44, 145-156. [CrossRef]

25. Wallace, D.R.; Taalab, Y.M.; Heinze, S.; Lovaković, B.T.; Pizent, A.; Renieri, E.; Tsatsakis, A.; Farooqi, A.A.; Javorac, D.; Andjelkovic, M.; et al. Toxic-Metal-Induced Alteration in miRNA Expression Profile as a Proposed Mechanism for Disease Development. Cells 2020, 9, 901. [CrossRef] [PubMed]

26. Wallace, D.R.; Buha-Đorđević, A.; Benton, A. Toxicity of organic and inorganic nickel in pancreatic cell cultures: Comparison to cadmium. Arh. za Farm. 2020, 70, 344-359. [CrossRef]

27. Bartel, D.P. MicroRNAs. Cell 2004, 116, 281-297. [CrossRef]

28. Lin, S.; Gregory, R.I. MicroRNA biogenesis pathways in cancer. Nat. Rev. Cancer 2015, 15, 321-333. [CrossRef]

29. Słotwiński, R.; Lech, G.; Słotwińska, S.M. MicroRNAs in pancreatic cancer diagnosis and therapy. Central Eur. J. Immunol. 2018, 43, 314-324. [CrossRef] [PubMed]

30. Meltzer, P.S. Small RNAs with big impacts. Nat. Cell Biol. 2005, 435, 745-746. [CrossRef]

31. Amirkhah, R.; Schmitz, U.; Linnebacher, M.; Wolkenhauer, O.; Farazmand, A. MicroRNA-mRNA interactions in colorectal cancer and their role in tumor progression. Genes Chromosom. Cancer 2015, 54, 129-141. [CrossRef] [PubMed]

32. Kalluri, R.; Weinberg, R.A. The basics of epithelial-mesenchymal transition. J. Clin. Investig. 2009, 119, 1420-1428. [CrossRef] [PubMed]

33. Galasso, M.; Sandhu, S.K.; Volinia, S. MicroRNA Expression Signatures in Solid Malignancies. Cancer J. 2012, 18, $238-243$. [CrossRef]

34. Yu, I.S.; Cheung, W.Y. A Contemporary Review of the Treatment Landscape and the Role of Predictive and Prognostic Biomarkers in Pancreatic Adenocarcinoma. Can. J. Gastroenterol. Hepatol. 2018, 2018, 1-10. [CrossRef] [PubMed]

35. Gilles, M.-E.; Hao, L.; Huang, L.; Rupaimoole, R.; López-Casas, P.P.; Pulver, E.; Jeong, J.C.; Muthuswamy, S.K.; Hidalgo, M.; Bhatia, S.N.; et al. Personalized RNA Medicine for Pancreatic Cancer. Clin. Cancer Res. 2018, 24, 1734-1747. [CrossRef]

36. Jay, C.; Nemunaitis, J.; Chen, P.; Fulgham, P.; Tong, A.W. miRNA Profiling for Diagnosis and Prognosis of Human Cancer. DNA Cell Biol. 2007, 26, 293-300. [CrossRef] 
37. Truty, M.J.; Urrutia, R. Basics of TGF-ß and Pancreatic Cancer. Pancreatology 2007, 7, 423-435. [CrossRef]

38. Birchenall-Roberts, M.C.; Fu, T.; Bang, O.-S.; Dambach, M.; Resau, J.H.; Sadowski, C.L.; Bertolette, D.C.; Lee, H.-J.; Kim, S.-J.; Ruscetti, F.W. Tuberous Sclerosis Complex 2 Gene Product Interacts with Human SMAD Proteins. J. Biol. Chem. 2004, 279, 25605-25613. [CrossRef]

39. Ellenrieder, V.; Hendler, S.F.; Boeck, W.; Seufferlein, T.; Menke, A.; Ruhland, C.; Adler, G.; Gress, T.M. Transforming growth factor beta1 treatment leads to an epithelial-mesenchymal transdifferentiation of pancreatic cancer cells requiring extracellular signal-regulated kinase 2 activation. Cancer Res. 2001, 61, 4222-4228. [PubMed]

40. McCleary-Wheeler, A.L.; McWilliams, R.; Fernandez-Zapico, M.E. Aberrant signaling pathways in pancreatic cancer: A two compartment view. Mol. Carcinog. 2011, 51, 25-39. [CrossRef]

41. Blackford, A.; Serrano, O.K.; Wolfgang, C.L.; Parmigiani, G.; Jones, S.; Zhang, X.; Parsons, D.W.; Lin, J.C.-H.; Leary, R.J.; Eshleman, J.R.; et al. SMAD4 Gene Mutations Are Associated with Poor Prognosis in Pancreatic Cancer. Clin. Cancer Res. 2009, 15, 4674-4679. [CrossRef] [PubMed]

42. Iacobuzio-Donahue, C.A.; Fu, B.; Yachida, S.; Luo, M.; Abe, H.; Henderson, C.M.; Vilardell, F.; Wang, Z.; Keller, J.W.; Banerjee, P.; et al. DPC4 Gene Status of the Primary Carcinoma Correlates with Patterns of Failure in Patients with Pancreatic Cancer. J. Clin. Oncol. 2009, 27, 1806-1813. [CrossRef] [PubMed]

43. Mu, Y.; Gudey, S.K.; Landström, M. Non-Smad signaling pathways. Cell Tissue Res. 2011, 347, 11-20. [CrossRef] [PubMed]

44. Li, L.; Li, Z.; Kong, X.; Xie, D.; Jia, Z.; Jiang, W.; Cui, J.; Du, Y.; Wei, D.; Huang, S.; et al. Down-regulation of MicroRNA-494 via Loss of SMAD4 Increases FOXM1 and $\beta$-Catenin Signaling in Pancreatic Ductal Adenocarcinoma Cells. Gastroenterology 2014, 147, 485-497.e18. [CrossRef]

45. Garajová, I.; Giovannetti, E.; Caponi, S.; Van Zweeden, A.; Peters, G.J. MiRNAs and Their Interference with the Main Molecular Mechanisms Responsible for Drug Resistance in Pancreatic Cancer. Curr. Pharmacol. Rep. 2015, 1, 223-233. [CrossRef]

46. Hao, J.; Zhang, S.; Zhou, Y.; Liu, C.; Hu, X.; Shao, C. MicroRNA 421 suppresses DPC4/Smad4 in pancreatic cancer. Biochem. Biophys. Res. Commun. 2011, 406, 552-557. [CrossRef] [PubMed]

47. Hao, J.; Zhang, S.; Zhou, Y.; Hu, X.; Shao, C. MicroRNA 483-3p suppresses the expression of DPC4/Smad4 in pancreatic cancer. FEBS Lett. 2010, 585, 207-213. [CrossRef]

48. Delitto, D. c-Met signaling in the development of tumorigenesis and chemoresistance: Potential applications in pancreatic cancer. World J. Gastroenterol. 2014, 20, 8458-8470. [CrossRef] [PubMed]

49. Zhu, G.-H.; Huang, C.; Qiu, Z.-J.; Liu, J.; Zhang, Z.-H.; Zhao, N.; Feng, Z.-Z.; Lv, X.-H. Expression and Prognostic Significance of CD151, c-Met, and Integrin alpha3/alpha6 in Pancreatic Ductal Adenocarcinoma. Dig. Dis. Sci. 2010, 56, 1090-1098. [CrossRef] [PubMed]

50. Shah, A.N.; Summy, J.M.; Zhang, J.; Park, S.I.; Parikh, N.U.; Gallick, G.E. Development and Characterization of GemcitabineResistant Pancreatic Tumor Cells. Ann. Surg. Oncol. 2007, 14, 3629-3637. [CrossRef]

51. Bao, B.; Wang, Z.; Ali, S.; Ahmad, A.; Azmi, A.S.; Sarkar, S.H.; Banerjee, S.; Kong, D.; Li, Y.; Thakur, S.; et al. Metformin Inhibits Cell Proliferation, Migration and Invasion by Attenuating CSC Function Mediated by Deregulating miRNAs in Pancreatic Cancer Cells. Cancer Prev. Res. 2012, 5, 355-364. [CrossRef]

52. Wu, K.; Hu, G.; He, X.; Zhou, P.; Li, J.; He, B.; Sun, W. MicroRNA-424-5p Suppresses the Expression of SOCS6 in Pancreatic Cancer. Pathol. Oncol. Res. 2013, 19, 739-748. [CrossRef] [PubMed]

53. Patel, K.; Kollory, A.; Takashima, A.; Sarkar, S.; Faller, D.V.; Ghosh, S.K. MicroRNA let-7 downregulates STAT3 phosphorylation in pancreatic cancer cells by increasing SOCS3 expression. Cancer Lett. 2014, 347, 54-64. [CrossRef] [PubMed]

54. Yonemori, K.; Kurahara, H.; Maemura, K.; Natsugoe, S. MicroRNA in pancreatic cancer. J. Hum. Genet. 2016, 62, 33-40. [CrossRef]

55. Hou, B.-H.; Jian, Z.-X.; Cui, P.; Li, S.-J.; Tian, R.-Q.; Ou, J.-R. miR-216a may inhibit pancreatic tumor growth by targeting JAK. FEBS Lett. 2015, 589, 2224-2232. [CrossRef] [PubMed]

56. Zhao, G.; Zhang, J.-G.; Shi, Y.; Qin, Q.; Liu, Y.; Wang, B.; Tian, K.; Deng, S.-C.; Li, X.; Zhu, S.; et al. MiR-130b Is a Prognostic Marker and Inhibits Cell Proliferation and Invasion in Pancreatic Cancer through Targeting STAT3. PLoS ONE 2013, 8, e73803. [CrossRef]

57. Huang, C.; Li, H.; Wu, W.; Jiang, T.; Qiu, Z. Regulation of miR-155 affects pancreatic cancer cell invasiveness and migration by modulating the STAT3 signaling pathway through SOCS1. Oncol. Rep. 2013, 30, 1223-1230. [CrossRef]

58. Ferro, R. Emerging role of the KRAS-PDK1 axis in pancreatic cancer. World J. Gastroenterol. 2014, 20, 10752-10757. [CrossRef]

59. Park, J.-K.; Lee, E.J.; Esau, C.; Schmittgen, T.D. Antisense Inhibition of microRNA-21 or -221 Arrests Cell Cycle, Induces Apoptosis, and Sensitizes the Effects of Gemcitabine in Pancreatic Adenocarcinoma. Pancreas 2009, 38, e190-e199. [CrossRef]

60. Sarkar, S.; Dubaybo, H.; Ali, S.; Goncalves, P.; Kollepara, S.L.; Sethi, S.; Philip, P.A.; Li, Y. Down-regulation of miR-221 inhibits prolif-eration of pancreatic cancer cells through up-regulation of PTEN, p27(kip1), p57(kip2), and PUMA. Am. J. Cancer Res. 2013, 3, 465-477.

61. Liu, J.; Xu, D.; Wang, Q.; Zheng, D.; Jiang, X.; Xu, L. LPS Induced miR-181a Promotes Pancreatic Cancer Cell Migration via Targeting PTEN and MAP2K4. Dig. Dis. Sci. 2014, 59, 1452-1460. [CrossRef]

62. Arisan, E.; Rencuzogullari, O.; Cieza-Borrella, C.; Arenas, F.M.; Dwek, M.; Lange, S.; Uysal-Onganer, P. MiR-21 is Required for the Epithelial-Mesenchymal Transition in MDA-MB-231 Breast Cancer Cells. Int. J. Mol. Sci. 2021, 22, 1557. [CrossRef] [PubMed] 
63. Uysal-Onganer, P.; D’Alessio, S.; Mortoglou, M.; Kraev, I.; Lange, S. Peptidylarginine Deiminase Inhibitor Application, Using Cl-Amidine, PAD2, PAD3 and PAD4 Isozyme-Specific Inhibitors in Pancreatic Cancer Cells, Reveals Roles for PAD2 and PAD3 in Cancer Invasion and Modulation of Extracellular Vesicle Signatures. Int. J. Mol. Sci. 2021, 22, 1396. [CrossRef] [PubMed]

64. Zhou, J.; Song, S.; He, S.; Zhu, X.; Zhang, Y.; Yi, B.; Zhang, B.; Qin, G.; Li, D. MicroRNA-375 targets PDK1 in pancreatic carcinoma and suppresses cell growth through the Akt signaling pathway. Int. J. Mol. Med. 2014, 33, 950-956. [CrossRef]

65. Yu, J.; Ohuchida, K.; Mizumoto, K.; Sato, N.; Kayashima, T.; Fujita, H.; Nakata, K.; Tanaka, M. MicroRNA, hsa-miR-200c, is an independent prognostic factor in pancreatic cancer and its upregulation inhibits pancreatic cancer invasion but increases cell proliferation. Mol. Cancer 2010, 9, 169. [CrossRef] [PubMed]

66. Radhakrishnan, P.; Mohr, A.M.; Grandgenett, P.M.; Steele, M.M.; Batra, S.K.; Hollingsworth, M.A. MicroRNA-200c Modulates the Expression of MUC4 and MUC16 by Directly Targeting Their Coding Sequences in Human Pancreatic Cancer. PLoS ONE 2013, 8 , e73356. [CrossRef]

67. Rachagani, S.; Macha, M.A.; Ponnusamy, M.P.; Haridas, D.; Kaur, S.; Jain, M.; Batra, S.K. MUC4 Potentiates Invasion and Metastasis of Pancreatic Cancer Cells through Stabilization of Fibroblast Growth Factor Receptor 1. Carcinogenesis 2012, 33, 1953-1964. [CrossRef]

68. Kaur, S.; Sharma, N.; Krishn, S.R.; Lakshmanan, I.; Rachagani, S.; Baine, M.J.; Smith, L.M.; Lele, S.M.; Sasson, A.R.; Guha, S.; et al. MUC4-Mediated Regulation of Acute Phase Protein Lipocalin 2 through HER2/AKT/NF-kB Signaling in Pancreatic Cancer. Clin. Cancer Res. 2014, 20, 688-700. [CrossRef]

69. Bardeesy, N.; Depinho, R.A. Pancreatic Cancer Biology and Genetics. Nat. Rev. Cancer 2002, 2, 897-909. [CrossRef] [PubMed]

70. Rozenblum, E.; Schutte, M.; Goggins, M.; Hahn, S.A.; Panzer, S.; Zahurak, M.; Goodman, S.N.; Sohn, T.A.; Hruban, R.H.; Yeo, C.J.; et al. Tumour-Suppressive Pathways in Pancreatic Carcinoma. Cancer Res. 1997, 57, 1731-1734. [PubMed]

71. Nalls, D.; Tang, S.-N.; Rodova, M.; Srivastava, R.K.; Shankar, S. Targeting Epigenetic Regulation of miR-34a for Treatment of Pancreatic Cancer by Inhibition of Pancreatic Cancer Stem Cells. PLoS ONE 2011, 6, e24099. [CrossRef]

72. Greither, T.; Grochola, L.F.; Udelnow, A.; Lautenschläger, C.; Würl, P.; Taubert, H. Elevated Expression of microRNAs 155, 203, 210 and 222 in Pancreatic Tumors is Associated with Poorer Survival. Int. J. Cancer 2009, 126, 73-80. [CrossRef]

73. Gironella, M.; Seux, M.; Xie, M.-J.; Cano, C.; Tomasini, R.; Gommeaux, J.; Garcia, S.; Nowak, J.; Yeung, M.L.; Jeang, K.-T.; et al. Tumor protein 53-induced nuclear protein 1 expression is repressed by miR-155, and its restoration inhibits pancreatic tumor development. Proc. Natl. Acad. Sci. USA 2007, 104, 16170-16175. [CrossRef] [PubMed]

74. Fulda, S. Apoptosis Pathways and Their Therapeutic Exploitation in Pancreatic Cancer. J. Cell. Mol. Med. 2009, 13, 1221-1227. [CrossRef]

75. Arlt, A.; Müerköster, S.S.; Schäfer, H. Targeting Apoptosis Pathways in Pancreatic Cancer. Cancer Lett. 2013, 332, 346-358. [CrossRef] [PubMed]

76. Liu, R.; Zhang, H.; Wang, X.; Zhou, L.; Likun, Z.; Deng, T.; Qu, Y.; Duan, J.; Bai, M.; Ge, S.; et al. The miR-24-Bim Pathway Promotes Tumor Growth and Angiogenesis in Pancreatic Carcinoma. Oncotarget 2015, 6, 43831-43842. [CrossRef] [PubMed]

77. Kanda, M.; Matthaei, H.; Wu, J.; Hong, S.; Yu, J.; Borges, M.; Hruban, R.H.; Maitra, A.; Kinzler, K.; Vogelstein, B.; et al. Presence of Somatic Mutations in Most Early-Stage Pancreatic Intraepithelial Neoplasia. Gastroenterology 2012, 142, 730-733.e9. [CrossRef]

78. Timar, J.; Kashofer, K. Molecular epidemiology and diagnostics of KRAS mutations in human cancer. Cancer Metastasis Rev. 2020, 39, 1029-1038. [CrossRef] [PubMed]

79. Zhao, W.-G.; Yu, S.-N.; Lu, Z.-H.; Ma, Y.-H.; Gu, Y.-M.; Chen, J. The miR-217 microRNA functions as a potential tumor suppressor in pancreatic ductal adenocarcinoma by targeting KRAS. Carcinogenesis 2010, 31, 1726-1733. [CrossRef] [PubMed]

80. Yu, S.; Lu, Z.; Liu, C.; Meng, Y.; Ma, Y.; Zhao, W.; Liu, J.; Yu, J.; Chen, J. miRNA-96 Suppresses KRAS and Functions as a Tumor Suppressor Gene in Pancreatic Cancer. Cancer Res. 2010, 70, 6015-6025. [CrossRef]

81. Jiao, L.R.; Frampton, A.E.; Jacob, J.; Pellegrino, L.; Krell, J.; Giamas, G.; Tsim, N.; Vlavianos, P.; Cohen, P.; Ahmad, R.; et al. MicroRNAs Targeting Oncogenes Are Down-Regulated in Pancreatic Malignant Transformation from Benign Tumors. PLoS ONE 2012, 7, e32068. [CrossRef]

82. Talotta, F.; Cimmino, A.; Matarazzo, M.R.; Casalino, L.; De Vita, G.; D’Esposito, M.; Di Lauro, R.; Verde, P. An autoregulatory loop mediated by miR-21 and PDCD4 controls the AP-1 activity in RAS transformation. Oncogene 2008, 28, 73-84. [CrossRef]

83. Vorvis, C.; Koutsioumpa, M.; Iliopoulos, D. Developments in miRNA gene signaling pathways in pancreatic cancer. Future Oncol. 2016, 12, 1135-1150. [CrossRef]

84. Keklikoglou, I.; Hosaka, K.; Bender, C.M.; Bott, A.; Koerner, C.; Mitra, D.; Will, R.G.; Woerner, A.; Muenstermann, E.; Wilhelm, H.E.; et al. MicroRNA-206 functions as a pleiotropic modulator of cell proliferation, invasion and lymphangiogenesis in pancreatic adenocarcinoma by targeting ANXA2 and KRAS genes. Oncogene 2015, 34, 4867-4878. [CrossRef]

85. Ma, Y.; Yu, S.; Zhao, W.; Lu, Z.; Chen, J. miR-27a regulates the growth, colony formation and migration of pancreatic cancer cells by targeting Sprouty2. Cancer Lett. 2010, 298, 150-158. [CrossRef]

86. Kent, O.A.; Chivukula, R.R.; Mullendore, M.; Wentzel, E.A.; Feldmann, G.; Lee, K.H.; Liu, S.; Leach, S.D.; Maitra, A.; Mendell, J.T. Repression of the miR-143/145 cluster by oncogenic Ras initiates a tumor-promoting feed-forward pathway. Genes Dev. 2010, 24, 2754-2759. [CrossRef] [PubMed]

87. Efurukawa, T. Impacts of Activation of the Mitogen-Activated Protein Kinase Pathway in Pancreatic Cancer. Front. Oncol. 2015, 5, 23. [CrossRef] 
88. Eser, S.; Schnieke, A.; Schneider, G.; Saur, D. Oncogenic KRAS signalling in pancreatic cancer. Br. J. Cancer 2014, 111, 817-822. [CrossRef] [PubMed]

89. Collisson, E.A.; Trejo, C.L.; Silva, J.M.; Gu, S.; Korkola, J.E.; Heiser, L.M.; Charles, R.-P.; Rabinovich, B.A.; Hann, B.; Dankort, D.; et al. A Central Role for RAF $\rightarrow$ MEK $\rightarrow$ ERK Signaling in the Genesis of Pancreatic Ductal Adenocarcinoma. Cancer Discov. 2012, 2, 685-693. [CrossRef] [PubMed]

90. Miyamoto, Y.; Maitra, A.; Ghosh, B.; Zechner, U.; Argani, P.; Iacobuzio-Donahue, C.A.; Sriuranpong, V.; Iso, T.; Meszoely, I.M.; Wolfe, M.S.; et al. Notch mediates TGF $\alpha$-induced changes in epithelial differentiation during pancreatic tumorigenesis. Cancer Cell 2003, 3, 565-576. [CrossRef]

91. Friess, H.; Yamanaka, Y.; Kobrin, M.S.; Do, D.A.; Buchler, M.W.; Korc, M. Enhanced erbB-3 expression in human pancreatic cancer correlates with tumour progression. Clin. Cancer Res. 1995, 1, 1413-1420. [PubMed]

92. Ueda, S.; Ogata, S.; Tsuda, H.; Kawarabayashi, N.; Kimura, M.; Sugiura, Y.; Tamai, S.; Matsubara, O.; Hatsuse, K.; Mochizuki, $\mathrm{H}$. The Correlation Between Cytoplasmic Overexpression of Epidermal Growth Factor Receptor and Tumor Aggressiveness. Pancreas 2004, 29, e1-e8. [CrossRef]

93. Ali, S.; Ahmad, A.; Aboukameel, A.; Ahmed, A.; Bao, B.; Banerjee, S.; Philip, P.A.; Sarkar, F.H. Deregulation of miR-146a Expression in a Mouse Model of Pancreatic Cancer Affecting EGFR Signaling. Cancer Lett. 2014, 351, 134-142. [CrossRef] [PubMed]

94. Du Rieu, M.C.; Torrisani, J.; Selves, J.; Al Saati, T.; Souque, A.; Dufresne, M.; Tsongalis, G.J.; Suriawinata, A.A.; Carrère, N.; Buscail, L.; et al. MicroRNA-21 Is Induced Early in Pancreatic Ductal Adenocarcinoma Precursor Lesions. Clin. Chem. 2010, 56, 603-612. [CrossRef] [PubMed]

95. Izumchenko, E.; Chang, X.; Michailidi, C.; Kagohara, L.; Ravi, R.; Paz, K.; Brait, M.; Hoque, M.O.; Ling, S.; Bedi, A.; et al. The TGF $\beta$-miR200-MIG6 Pathway Orchestrates the EMT-Associated Kinase Switch That Induces Resistance to EGFR Inhibitors Cancer Res. 2014, 74, 3995-4005. [CrossRef] [PubMed]

96. Li, X.; Zhao, H.; Gu, J.; Zheng, L. Prognostic role of HER2 amplification based on fluorescence in situ hybridization (FISH) in pancreatic ductal adenocarcinoma (PDAC): A meta-analysis. World J. Surg. Oncol. 2016, 14, 1-7. [CrossRef] [PubMed]

97. Aumayr, K.; Soleiman, A.; Sahora, K.; Schindl, M.; Werba, G.; Schoppmann, S.F.; Birner, P. HER2 Gene Amplification and Protein Expression in Pancreatic Ductal Adenocarcinomas. Appl. Immunohistochem. Mol. Morphol. 2014, 22, 146-152. [CrossRef] [PubMed]

98. Radtke, F.; Raj, K. The role of Notch in tumorigenesis: Oncogene or tumour suppressor? Nat. Rev. Cancer 2003, 3, 756-767. [CrossRef]

99. De Lao, J.-P.; Murtaugh, L.C. Notch and Kras in pancreatic cancer: At the crossroads of mutation, differentiation and signaling Cell Cycle 2009, 8, 1860-1864. [CrossRef] [PubMed]

100. Wang, Z.; Zhang, Y.; Li, Y.; Banerjee, S.; Liao, J.; Sarkar, F.H. Down-regulation of Notch-1 contributes to cell growth inhibition and apoptosis in pancreatic cancer cells. Mol. Cancer Ther. 2006, 5, 483-493. [CrossRef]

101. Ji, Q.; Hao, X.; Zhang, M.; Tang, W.; Yang, M.; Li, L.; Xiang, D.; DeSano, J.T.; Bommer, G.T.; Fan, D.; et al. MicroRNA miR-34 Inhibits Human Pancreatic Cancer Tumor-Initiating Cells. PLoS ONE 2009, 4, e6816. [CrossRef]

102. Brabletz, S.; Bajdak, K.; Meidhof, S.; Burk, U.; Niedermann, G.; Firat, E.; Wellner, U.; Dimmler, A.; Faller, G.; Schubert, J.; et al. The ZEB1/miR-200 feedback loop controls Notch signalling in cancer cells. EMBO J. 2011, 30, 770-782. [CrossRef]

103. Sureban, S.M.; May, R.; Qu, D.; Weygant, N.; Chandrakesan, P.; Ali, N.; Lightfoot, S.A.; Pantazis, P.; Rao, C.V.; Postier, R.G.; et al DCLK1 Regulates Pluripotency and Angiogenic Factors via microRNA-Dependent Mechanisms in Pancreatic Cancer. PLoS ONE 2013, 8, e73940. [CrossRef]

104. Altaba, A.R.I.; Sánchez, P.; Dahmane, N. Gli and hedgehog in cancer: Tumours, embryos and stem cells. Nat. Rev. Cancer 2002, 2, 361-372. [CrossRef]

105. Thayer, S.P.; di Magliano, M.P.; Heiser, P.W.; Nielsen, C.M.; Roberts, D.J.; Lauwers, G.Y.; Qi, Y.P. Hedgehog is an early and late mediator of pancreatic cancer tumourigenesis. Nature 2003, 425, 851-856. [CrossRef] [PubMed]

106. Dosch, J.S.; Di Magliano, M.P.; Simeone, D.M. Pancreatic Cancer and Hedgehog Pathway Signaling: New Insights. Pancreatology 2010, 10, 151-157. [CrossRef]

107. Ma, C.; Nong, K.; Wu, B.; Dong, B.; Bai, Y.; Zhu, H.; Wang, W.; Huang, X.; Yuan, Z.; Ai, K. miR-212 promotes pancreatic cancer cell growth and invasion by targeting the hedgehog signaling pathway receptor patched-1. J. Exp. Clin. Cancer Res. 2014, 33, 54. [CrossRef] [PubMed]

108. Jiang, J.; Yu, C.; Chen, M.; Zhang, H.; Tian, S.; Sun, C. Reduction of miR-29c enhances pancreatic cancer cell migration and stem cell-like phenotype. Oncotarget 2014, 6, 2767-2778. [CrossRef] [PubMed]

109. Nagano, H.; Tomimaru, Y.; Eguchi, H.; Hama, N.; Wada, H.; Kawamoto, K.; Kobayashi, S.; Mori, M.; Doki, Y. MicroRNA-29a induces resistance to gemcitabine through the Wnt/ $\beta$-catenin signaling pathway in pancreatic cancer cells. Int. J. Oncol. 2013, 43, 1066-1072. [CrossRef]

110. Zeng, G.; Germinaro, M.; Micsenyi, A.; Monga, N.K.; Bell, A.; Sood, A.; Malhotra, V.; Sood, N.; Midda, V.; Monga, D.K.; et al. Aberrant Wnt/ $\beta$-Catenin Signaling in Pancreatic Adenocarcinoma. Neoplasia 2006, 8, 279-289. [CrossRef]

111. Lowy, A.M.; Fenoglio-Preiser, C.; Kim, O.J.; Kordich, J.; Gómez, A.; Knight, J.; James, L.; Groden, J. Dysregulation of $\beta$-Catenin Expression Correlates with Tumor Differentiation in Pancreatic Duct Adenocarcinoma. Ann. Surg. Oncol. 2003, 10, 284-290. [CrossRef] 
112. Santo, L.; Siu, K.T.; Raje, N. Targeting Cyclin-Dependent Kinases and Cell Cycle Progression in Human Cancers. Semin. Oncol. 2015, 42, 788-800. [CrossRef] [PubMed]

113. Chen, J.; Li, D.; Killary, A.M.; Sen, S.; Amos, C.I.; Evans, D.B.; Abbruzzese, J.L.; Frazier, M.L. Polymorphisms of p16, p27, p73, and MDM2 Modulate Response and Survival of Pancreatic Cancer Patients Treated with Preoperative Chemoradiation. Ann. Surg. Oncol. 2008, 16, 431-439. [CrossRef] [PubMed]

114. Lee, K.-H.; Lotterman, C.; Karikari, C.; Omura, N.; Feldmann, G.; Habbe, N.; Goggins, M.G.; Mendell, J.T.; Maitra, A. Epigenetic Silencing of MicroRNA miR-107 Regulates Cyclin-Dependent Kinase 6 Expression in Pancreatic Cancer. Pancreatology 2009, 9 , 293-301. [CrossRef] [PubMed]

115. Zhao, C.; Zhang, J.; Zhang, S.; Yu, D.; Chen, Y.; Liu, Q.; Shi, M.; Ni, C.; Zhu, M. Diagnostic and biological significance of microRNA-192 in pancreatic ductal adenocarcinoma. Oncol. Rep. 2013, 30, 276-284. [CrossRef] [PubMed]

116. Chen, Z.; Chen, L.-Y.; Dai, H.-Y.; Wang, P.; Gao, S.; Wang, K. miR-301a promotes pancreatic cancer cell proliferation by directly inhibiting bim expression. J. Cell. Biochem. 2012, 113, 3229-3235. [CrossRef]

117. Willis, S.N.; Chen, L.; Dewson, G.; Wei, A.; Naik, E.; Fletcher, J.I.; Adams, J.M.; Huang, D.C. Proapoptotic Bak is sequestered by Mcl-1 and Bcl-xL, but not Bcl-2, until displaced by BH3-only proteins. Genes Dev. 2005, 19, 1294-1305. [CrossRef] [PubMed]

118. Jin, X.; Sun, Y.; Yang, H.; Li, J.; Yu, S.; Chang, X.; Lu, Z.; Chen, J. Deregulation of the MiR-193b-KRAS Axis Contributes to Impaired Cell Growth in Pancreatic Cancer. PLoS ONE 2015, 10, e0125515. [CrossRef] [PubMed]

119. Ma, J.; Fang, B.; Zeng, F.; Ma, C.; Pang, H.; Cheng, L.; Shi, Y.; Wang, H.; Yin, B.; Xia, J.; et al. Down-regulation of miR-223 reverses epithelial-mesenchymal transition in gemcitabine-resistant pancreatic cancer cells. Oncotarget 2015, 6, 1740-1749. [CrossRef]

120. Zhao, Y.; Wang, Y.; Yang, Y.; Liu, J.; Song, Y.; Cao, Y.; Chen, X.; Yang, W.; Wang, F.; Gao, J.; et al. MicroRNA-222 Controls Human Pancreatic Cancer Cell Line Capan-2 Proliferation by P57 Targeting. J. Cancer 2015, 6, 1230-1235. [CrossRef]

121. Boutros, R.; Lobjois, V.; Ducommun, B. CDC25 phosphatases in cancer cells: Key players? Good targets? Nat. Rev. Cancer 2007, 7, 495-507. [CrossRef]

122. Liffers, S.-T.; Munding, J.B.; Vogt, M.; Kuhlmann, J.D.; Verdoodt, B.; Nambiar, S.; Maghnouj, A.; Mirmohammadsadegh, A.; Hahn, S.A.; Tannapfel, A. MicroRNA-148a is down-regulated in human pancreatic ductal adenocarcinomas and regulates cell survival by targeting CDC25B. Lab. Investig. 2011, 91, 1472-1479. [CrossRef] [PubMed]

123. Schutte, M.; Hruban, R.H.; Geradts, J.; Maynard, R.; Hilgers, W.; Rabindran, S.K.; Moskaluk, C.A.; Hahn, S.A.; Schwarte-Waldhoff, I.; Schmiegel, W.; et al. Abrogation of the Rb/p16 tumour-suppressive pathway in virtually all pan-creatic carcinomas. Cancer Res. 1997, 57, 3126-3130. [PubMed]

124. Sharpless, N.E.; DePinho, R.A. Cancer: Crime and punishment. Nature 2005, 436, 636-637. [CrossRef] [PubMed]

125. Wilentz, R.E.; Geradts, J.; Maynard, R.; Offerhaus, G.J.A.; Kang, M.; Goggins, M.; Yeo, C.J.; Kern, S.E.; Hruban, R.H. Inactivation of the p16 (INK4A) tumour-suppressor gene in pancreatic duct lesions: Loss of intranuclear expression. Cancer Res. 1998, 58, 4740-4744.

126. Partensky, C. Toward a Better Understanding of Pancreatic Ductal Adenocarcinoma. Pancreas 2013, 42, 729-739. [CrossRef]

127. Okamoto, A.; Demetrick, D.J.; Spillare, E.A.; Hagiwara, K.; Hussain, S.P.; Bennett, W.P.; Forrester, K.; Gerwin, B.; Serrano, M.; Beach, D.H. Mutations and altered expression of p16INK4 in human cancer. Proc. Natl. Acad. Sci. USA 1994, 91, 11045-11049. [CrossRef]

128. Medina, R.F.; Zaidi, S.K.; Liu, C.-G.; Stein, J.L.; Van Wijnen, A.J.; Croce, C.M.; Stein, G.S. MicroRNAs 221 and 222 Bypass Quiescence and Compromise Cell Survival. Cancer Res. 2008, 68, 2773-2780. [CrossRef]

129. Park, J.-K.; Henry, J.C.; Jiang, J.; Esau, C.; Gusev, Y.; Lerner, M.R.; Postier, R.G.; Brackett, D.J.; Schmittgen, T.D. miR-132 and miR-212 are increased in pancreatic cancer and target the retinoblastoma tumor suppressor. Biochem. Biophys. Res. Commun. 2011, 406, 518-523. [CrossRef]

130. Zhao, L.; Zhao, H.; Yan, H. Gene expression profiling of 1200 pancreatic ductal adenocarcinoma reveals novel subtypes. BMC Cancer 2018, 18, 1-13. [CrossRef]

131. Nebert, D.W. Transcription factors and cancer: An overview. Toxicology 2002, 181-182, 131-141. [CrossRef]

132. Lomberk, G.A.; Urrutia, R. The Triple-Code Model for Pancreatic Cancer: Cross Talk Among Genetics, Epigenetics, and Nuclear Structure. Surg. Clin. N. Am. 2015, 95, 935-952. [CrossRef] [PubMed]

133. Farhan, M.; Wang, H.; Gaur, U.; Little, P.J.; Xu, J.; Zheng, W. FOXO Signaling Pathways as Therapeutic Targets in Cancer. Int. J. Biol. Sci. 2017, 13, 815-827. [CrossRef] [PubMed]

134. Roy, S.K.; Chen, Q.; Fu, J.; Shankar, S.; Srivastava, R.K. Resveratrol Inhibits Growth of Orthotopic Pancreatic Tumors through Activation of FOXO Transcription Factors. PLOS ONE 2011, 6, e25166. [CrossRef] [PubMed]

135. Song, W.; Liwei, W.; Wang, L.; Wang, L. Modulation of FoxO1 Expression by miR-21 to Promote Growth of Pancreatic Ductal Adenocarcinoma. Cell. Physiol. Biochem. 2015, 35, 184-190. [CrossRef] [PubMed]

136. Wang, P.; Zhu, C.-F.; Ma, M.-Z.; Chen, G.; Song, M.; Zeng, Z.-L.; Lu, W.-H.; Yang, J.; Wen, S.; Chiao, P.J.; et al. Micro-RNA-155 is induced by K-Ras oncogenic signal and promotes ROS stress in pancreatic cancer. Oncotarget 2015, 6, 21148-21158. [CrossRef] [PubMed]

137. Bao, B.; Wang, Z.; Ali, S.; Kong, D.; Banerjee, S.; Ahmad, A.; Li, Y.; Azmi, A.S.; Miele, L.; Sarkar, F.H. Over-expression of FoxM1 leads to epithelial-mesenchymal transition and cancer stem cell phenotype in pancreatic cancer cells. J. Cell. Biochem. 2011, 112, 2296-2306. [CrossRef] 
138. Fujioka, S.; Sclabas, G.M.; Schmidt, C.; Frederick, W.A.; Dong, Q.G.; Abbruzzese, J.L.; Evans, D.B.; Baker, C.; Chiao, P.J. Function of Nuclear Factor kappaB in Pancreatic Cancer Metastasis. Clin. Cancer Res. 2003, 9, 346-354. [PubMed]

139. Li, Y.; Vandenboom, T.G.; Wang, Z.; Kong, D.; Ali, S.; Philip, P.A.; Sarkar, F.H. miR-146a Suppresses Invasion of Pancreatic Cancer Cells. Cancer Res. 2010, 70, 1486-1495. [CrossRef] [PubMed]

140. Lu, Z.; Li, Y.; Takwi, A.; Li, B.; Zhang, J.; Conklin, D.J.; Young, K.H.; Martin, R.; Li, Y. miR-301a as an NF-kB activator in pancreatic cancer cells. EMBO J. 2010, 30, 57-67. [CrossRef]

141. Denis, H.; Ndlovu, M.N.; Fuks, F. Regulation of Mammalian DNA Methyltransferases: A Route to New Mechanisms. EMBO Rep. 2011, 12, 647-656. [CrossRef]

142. Dhe-Paganon, S.; Syeda, F.; Park, L. DNA methyl Transferase 1: Regulatory mechanisms and implications in health and disease. Int. J. Biochem. Mol. Boil. 2011, 2, 58-66.

143. Azizi, M.; Teimoori-Toolabi, L.; Arzanani, M.K.; Azadmanesh, K.; Fard-Esfahani, P.; Zeinali, S. MicroRNA-148b and microRNA152 reactivate tumor suppressor genes through suppression of DNA methyltransferase-1 gene in pancreatic cancer cell lines. Cancer Biol. Ther. 2014, 15, 419-427. [CrossRef] [PubMed]

144. Moroishi, T.; Hansen, C.G.; Guan, K.-L. The emerging roles of YAP and TAZ in cancer. Nat. Rev. Cancer 2015, 15, 73-79. [CrossRef] [PubMed]

145. Chen, W.Y.; Yuan, H.; Su, L. The emerging and diverse roles of sirtuins in cancer: A clinical perspective. OncoTargets Ther. 2013, 6, 1399-1416. [CrossRef] [PubMed]

146. Deng, S.; Zhu, S.; Wang, B.; Li, X.; Liu, Y.; Qin, Q.; Gong, Q.; Niu, Y.; Xiang, C.; Chen, J.; et al. Chronic pancreatitis and pancreatic cancer demonstrate active epithelial-mesenchymal transition profile, regulated by miR-217-SIRT1 pathway. Cancer Lett. 2014, 355, 184-191. [CrossRef]

147. Ye, X.; Wei, X.; Liao, J.; Chen, P.; Li, X.; Chen, Y.; Yang, Y.; Zhao, Q.; Sun, H.; Pan, L.; et al. 4-Hydroxyphenylpyruvate Dioxygenase-Like Protein Promotes Pancreatic Cancer Cell Progression and Is Associated with Glutamine-Mediated Redox Balance. Front. Oncol. 2021, 10, 617190. [CrossRef]

148. Kim, J.; Lee, J.; Cho, Y.-R.; Lee, S.-Y.; Sung, G.-J.; Shin, D.-M.; Choi, K.-C.; Son, J. TFEB Supports Pancreatic Cancer Growth through the Transcriptional Regulation of Glutaminase. Cancers 2021, 13, 483. [CrossRef] [PubMed]

149. Srivastava, S.; Widmann, S.; Ho, C.; Nguyen, D.; Nguyen, A.; Premaratne, A.; Gustafsson, J.-Å.; Lin, C.-Y. Novel Liver X Receptor Ligand GAC0001E5 Disrupts Glutamine Metabolism and Induces Oxidative Stress in Pancreatic Cancer Cells. Int. J. Mol. Sci. 2020, 21, 9622. [CrossRef] [PubMed]

150. Ashrafizadeh, M.; Bakhoda, M.R.; Bahmanpour, Z.; Ilkhani, K.; Zarrabi, A.; Makvandi, P.; Khan, H.; Mazaheri, S.; Darvish, M.; Mirzaei, H. Apigenin as Tumor Suppressor in Cancers: Biotherapeutic Activity, Nanodelivery, and Mechanisms with Emphasis on Pancreatic Cancer. Front. Chem. 2020, 8, 829. [CrossRef]

151. Cinque, G.; Ferino, A.; Pedersen, E.B.; Xodo, L.E. Role of Poly [ADP-ribose] Polymerase 1 in Activating the Kirsten ras (KRAS) Gene in Response to Oxidative Stress. Int. J. Mol. Sci. 2020, 21, 6237. [CrossRef]

152. Kim, H.-J.; Kim, D.; Yoon, H.; Choi, C.S.; Oh, Y.S.; Jun, H.-S. Prevention of Oxidative Stress-Induced Pancreatic Beta Cell Damage by Broussonetia kazinoki Siebold Fruit Extract via the ERK-Nox4 Pathway. Antioxidants 2020, 9, 406. [CrossRef] [PubMed]

153. Gibson, A.R.; O’Leary, B.R.; Du, J.; Sarsour, E.H.; Kalen, A.L.; Wagner, B.A.; Stolwijk, J.M.; Falls-Hubert, K.C.; Alexander, M.S.; Carroll, R.S.; et al. Dual Oxidase-Induced Sustained Generation of Hydrogen Peroxide Contributes to Pharmacologic Ascorbate-Induced Cytotoxicity. Cancer Res. 2020, 80, 1401-1413. [CrossRef]

154. Lee, S.-W.; Commisso, C. Metabolic regulation of EGFR effector and feedback signaling in pancreatic cancer cells requires K-Ras. Biochem. Biophys. Res. Commun. 2020, 533, 424-428. [CrossRef] [PubMed]

155. Recouvreux, M.V.; Moldenhauer, M.R.; Galenkamp, K.M.; Jung, M.; James, B.; Zhang, Y.; Lowy, A.; Bagchi, A.; Commisso, C. Glutamine depletion regulates Slug to promote EMT and metastasis in pancreatic cancer. J. Exp. Med. 2020, 217. [CrossRef]

156. Chen, Y.; Zhou, Y.; Han, F.; Zhao, Y.; Tu, M.; Wang, Y.; Huang, C.; Fan, S.; Chen, P.; Yao, X.; et al. A novel miR-1291-ERR $\alpha$-CPT1C axis modulates tumor cell proliferation, metabolism and tumorigenesis. Theranostics 2020, 10, 7193-7210. [CrossRef]

157. Wang, Y.; Yu, T.; Zhou, Y.; Wang, S.; Zhou, X.; Wang, L.; Ou, T.; Chen, Y.; Zhou, Y.; Zhang, H.; et al. Carnitine palmitoyltransferase $1 \mathrm{C}$ contributes to progressive cellular senescence. Aging 2020, 12, 6733-6755. [CrossRef]

158. Cannataro, R.; Perri, M.; Gallelli, L.; Caroleo, M.C.; De Sarro, G.; Cione, E. Ketogenic Diet Acts on Body Remodeling and MicroRNAs Expression Profile. MicroRNA 2019, 8, 116-126. [CrossRef]

159. Chang, T.-C.; Wentzel, E.A.; Kent, O.A.; Ramachandran, K.; Mullendore, M.; Lee, K.H.; Feldmann, G.; Yamakuchi, M.; Ferlito, M.; Lowenstein, C.J.; et al. Transactivation of miR-34a by p53 Broadly Influences Gene Expression and Promotes Apoptosis. Mol. Cell 2007, 26, 745-752. [CrossRef]

160. Guo, R.; Gu, J.; Zhang, Z.; Wang, Y.; Gu, C. MicroRNA-410 functions as a tumor suppressor by targeting angiotensin II type 1 receptor in pancreatic cancer. IUBMB Life 2015, 67, 42-53. [CrossRef] [PubMed]

161. Bao, B.; Ali, S.; Ahmad, A.; Azmi, A.S.; Li, Y.; Banerjee, S.; Kong, D.; Sethi, S.; Aboukameel, A.; Padhye, S.B.; et al. HypoxiaInduced Aggressiveness of Pancreatic Cancer Cells Is Due to Increased Expression of VEGF, IL-6 and miR-21, Which Can Be Attenuated by CDF Treatment. PLoS ONE 2012, 7, e50165. [CrossRef]

162. Khan, S.; Ansarullah; Kumar, D.; Jaggi, M.; Chauhan, S.C. Targeting microRNAs in pancreatic cancer: Microplayers in the big game. Cancer Res. 2013, 73, 6541-6547. [CrossRef] [PubMed] 
163. Mace, T.A.; Collins, A.L.; Wojcik, S.E.; Croce, C.M.; Lesinski, G.B.; Bloomston, M. Hypoxia induces the overexpression of microRNA-21 in pancreatic cancer cells. J. Surg. Res. 2013, 184, 855-860. [CrossRef] [PubMed]

164. Yang, W.; Yang, Y.; Xia, L.; Yang, Y.; Wang, F.; Song, M.; Chen, X.; Liu, J.; Song, Y.; Zhao, Y.; et al. MiR-221 Promotes Capan-2 Pancreatic Ductal Adenocarcinoma Cells Proliferation by Targeting PTEN-Akt. Cell. Physiol. Biochem. 2016, 38, $2366-2374$. [CrossRef] [PubMed] 